\title{
Temporal and Spatial Variations of Geodia cydonium (Jameson) (Porifera, Demospongiae) in the Mediterranean Confined Environments
}

\author{
Maria Mercurio ${ }^{1,2, *}$, Cataldo Pierri ${ }^{1,2}$ (D) Frine Cardone ${ }^{2,3}$ and Giuseppe Corriero ${ }^{1,2}$ \\ 1 Department of Biology, University of Bari Aldo Moro, Via Orabona, 4, 70125 Bari, Italy; \\ cataldo.pierri@uniba.it (C.P.); giuseppe.corriero@uniba.it (G.C.) \\ 2 CoNISMa, Consorzio Interuniversitario per le Scienze del Mare, 00196 Rome, Italy; frine.cardone@szn.it \\ 3 Integrative Marine Ecology Department, Zoological Station “Anton Dohrn", Villa Comunale, \\ 80121 Napoli, Italy \\ * Correspondence: maria.mercurio@uniba.it
}

Citation: Mercurio, M.; Pierri, C.; Cardone, F.; Corriero, G. Temporal and Spatial Variations of Geodia cydonium (Jameson) (Porifera, Demospongiae) in the Mediterranean Confined Environments. Diversity 2021, 13, 615. https://doi.org/ $0.3390 / \mathrm{d} 13120615$

Academic Editors: Michael Wink, Carlo Nike Bianchi and Carla Morri

Received: 28 October 2021

Accepted: 21 November 2021

Published: 25 November 2021

Publisher's Note: MDPI stays neutral with regard to jurisdictional claims in published maps and institutional affiliations.

Copyright: (c) 2021 by the authors. Licensee MDPI, Basel, Switzerland. This article is an open access article distributed under the terms and conditions of the Creative Commons Attribution (CC BY) license (https:/ / creativecommons.org/licenses/by/ $4.0 /)$.

\begin{abstract}
Confined marine environments are particularly susceptible to climate change and anthropic pressures. Indeed, the long-term monitoring of benthic assemblages in these environments allows us to understand the direction of changes over time. The demosponge Geodia cydonium is a suitable study case, since it is widely represented in many Mediterranean environments, while being a long-living and important habitat-forming species. Here, we report the results of a descriptive study on temporal and spatial variations of this demosponge in three semi-enclosed environments along the Italian coast: Marsala Lagoon, Porto Cesareo Bay, and Mar Piccolo of Taranto. At Marsala and Porto Cesareo, the study compares the present data with those reported by the literature at the end of the 1990s. Caused by the modification of its preferential habitats, the data indicated the loss and a remarkable regression of this species at Porto Cesareo and Marsala, respectively. In addition, we hypothesized that the increase in severe weather phenomena in the small Bay of Porto Cesareo recorded during the last 20 years may have had a marked impact on water mass, thus affecting the sponge assemblages. At Taranto, despite a remarkable environmental degradation, G. cydonium has appeared stable and persistent in the last 45 years, thus representing one of the richest and most well-preserved populations in the Mediterranean Sea.
\end{abstract}

Keywords: Geodia cydonium; temporal and spatial variations; mediterranean confined environments

\section{Introduction}

Important environmental changes, mostly linked to global warming and anthropic pressures, have affected biodiversity in several marine environments in recent decades [1-3]. Lagoon systems and semi-enclosed bays are particularly exposed to severe weather phenomena, as they are subjected to moderate water circulations and high anthropic pressures [4].

Lagoons are characterized by high sedimentation levels, and, although typically poor in natural hard substrates, there are a few exceptions (e.g., mangrove roots, phanerogam rhizomes, mollusk shells, and calcified bryozoan skeletons). However, human activities have led to the introduction of stone debris, ropes, and other material lost by farmers and fishermen, which have been successfully colonized by macrozoobenthic filter-feeders [5-7]. Able to colonize both natural and artificial substrates [8-10], sponges are often dominant components of these hard benthic communities; in some cases, they are also able to colonize lagoon soft bottoms, at infaunal and non-sessile levels [8,11-13].

According to the literature, the lagoon systems along the Italian coast with the highest sponge biodiversity are Marsala Lagoon (Tyrrhenian Sea) [8,11,14], Mar Piccolo of Taranto (Ionian Sea) $[8,13,15,16]$, and Porto Cesareo Bay (Ionian Sea) $[17,18]$. In these semi-enclosed environments, the demosponge Geodia cydonium (Jameson 1811) has been 
reported as a common and persistent species, which is able to colonize both hard and mobile substrates [19].

G. cydonium is a well-known Atlantic-Mediterranean demosponge, which is characterized by its highly variable shape, ranging from irregularly massive $[19,20]$, cushionencrusting [16], spherical, or sub-spherical [11], flattened [19] and columnar/cylindrical [21], to insinuating [22]. The mean diameter is approximately $10-20 \mathrm{~cm}$, although large specimens have also been reported, such as the individual of $29 \mathrm{~kg}$ in weight and $180 \mathrm{~cm}$ in diameter collected in the Northern Adriatic Sea [23]. G. cydonium was described as a long-living species with specimens that can reach several hundred years of age [24]. It is included in Annex II of the SPA/BIO Protocol of the Barcelona Convention and IUCN Red List of Threatened Species, where it is classified as endangered. Moreover, it is considered an important habitat-forming species that provides support and shelter for many benthic organisms $[25,26]$. Finally, interesting bioactive compounds have been extracted from tissues of this sponge cultivated in open systems [24].

The purpose of the present study was to investigate the temporal and spatial variations of some population parameters and morphological traits in G. cydonium inhabiting different confined environments along the South Italian coast, while also considering the main environmental changes that may have affected the study areas.

\section{Materials and Methods}

\subsection{Study Sites}

\subsubsection{Marsala Lagoon}

Marsala Lagoon (Trapani, NW Sicily) (Figure 1) covers an area of $20 \mathrm{~km}^{2}$ and is characterized by high water exchange mainly through the southern sea opening, thus reducing thermohaline oscillations in the wide lagoon portions [9]. The bottom is covered by fine sediments with considerable portions of coarse sand. The maximum depth is $2.5 \mathrm{~m}$ [27]. Hard substrates are mainly represented by algal or animal calcareous concretions, artificial concrete walls, and phanerogam rhizomes. Benthic fauna show the highest values of taxonomic richness among all lagoon environments in Italy [28]. Demosponges, in particular, are an important component of macrozoobenthos, which are represented by 47 species and high biomass values $[8,11,14,18]$.

At Marsala, G. cydonium settles primarily on the rhizomes of Posidonia oceanica between a 0.5 and $2 \mathrm{~m}$ depth $[11,19]$. It is also observed in non-sessile form, rolling over mobile substrates $[11,14,18,19,29,30]$. This assemblage of non-sessile specimens occurs in wide storage areas, represented by a $10 \mathrm{~m}$-wide and $2 \mathrm{~m}$-deep navigable channel, located in the central part of the lagoon $[19,30]$. According to the literature [8], the occurrence of this species in both sessile and non-sessile forms was reported over a period of 27 years (1983-2010).

\subsubsection{Mar Piccolo of Taranto}

Mar Piccolo of Taranto (Apulia), with a surface area of $20.72 \mathrm{~km}^{2}$, is a coastal brackish marine ecosystem located on the northern coast of the Gulf of Taranto (Southern Italy, Ionian Sea) (Figure 1). It is divided by a north-south oriented promontory into two smaller basins, namely, the first and the second inlet, which have maximum depths of 13 and $9 \mathrm{~m}$, respectively [31]. The system is characterized by a low seawater turnover and moderate currents, which are more intense in the second inlet [32]. The second inlet receives freshwater inflow from several small streams. Dissolved oxygen shows wide seasonal variability, and oxygen deficits can occur in the deep layers, thus leading to seasonal dystrophic crises [33]. Mar Piccolo of Taranto is mostly characterized by mobile substrates, partially colonized by seagrasses and turf-forming macroalgae. Hard substrates are also abundant and diversified, mainly consisting of stones and debris of human origin, and host rich assemblages of filter feeders (mainly poriferans, hydrozoans, polychaetes, bryozoans, bivalves, crinoids, and ascidians) forming multilayered assemblages (e.g., [7,34,35]). However, a remarkable change in sponge species composition was reported at the end of the last century. Indeed, 
from more than 30 species recorded between 1976 and 1983 [15,16], only seven of those were detected by Longo et al. [8] in the period between 2001 and 2004.

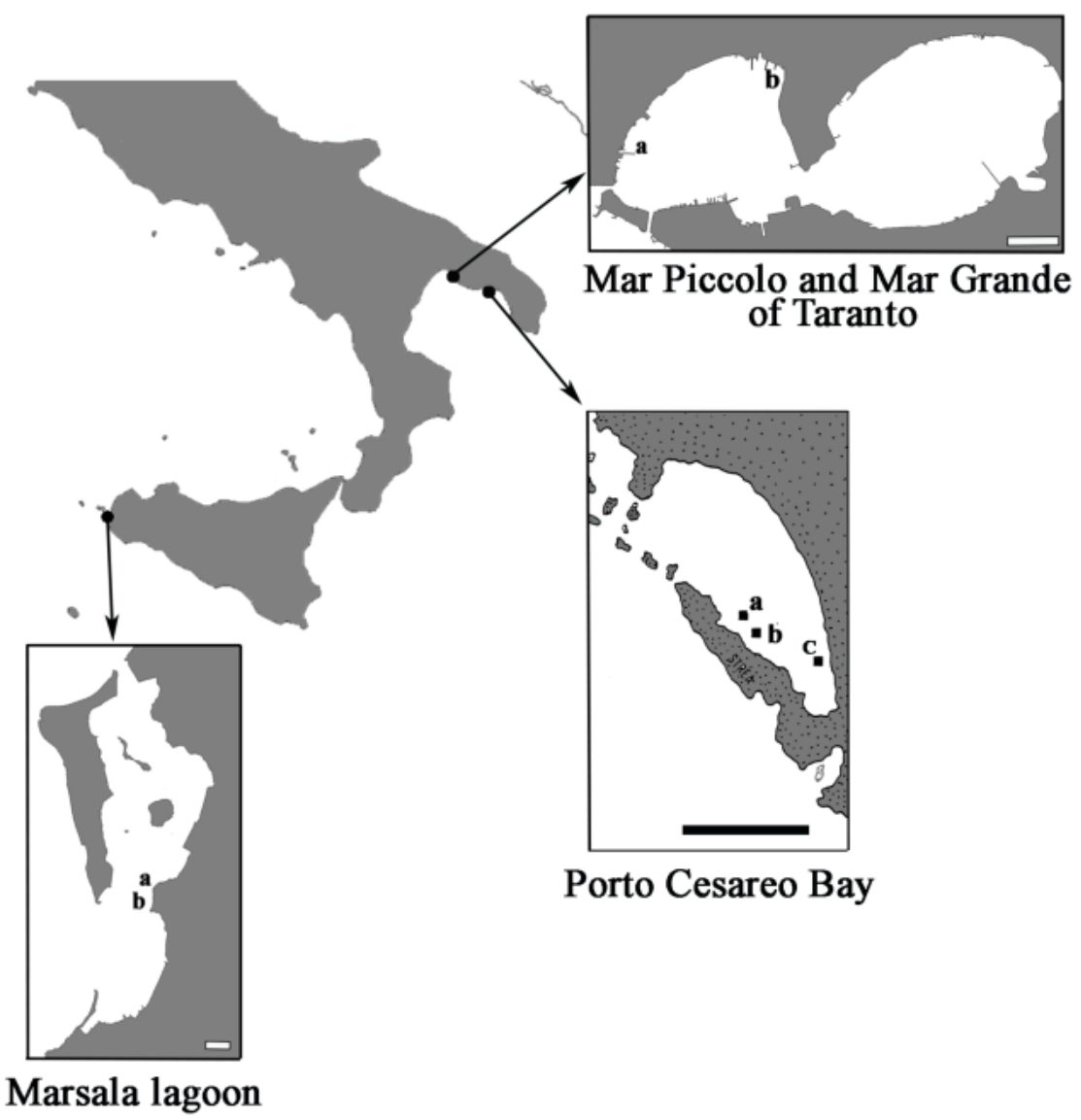

Figure 1. The study sites within the sampling areas: Marsala Lagoon (NW Sicily, $37^{\circ} 14^{\prime} ; 12^{\circ} 40^{\prime}$ ), Mar Piccolo of Taranto $\left(40^{\circ} 29^{\prime} ; 17^{\circ} 14^{\prime}\right)$, and Porto Cesareo Bay (SW Apulia, $\left.40^{\circ} 15^{\prime} ; 17^{\circ} 54^{\prime}\right)$. Small letters indicate sampling areas; in Porto Cesareo Bay, " $\mathrm{c}$ " indicates the additional sampling area. Scale bar $=1 \mathrm{~km}$.

The first record of G. cydonium in Mar Piccolo of Taranto is attributable to Scalera Liaci et al. [15]. The species was again reported by Pulitzer Finali [16] and Longo et al. [8] in a sponge list obtained from samples collected in 2010. In 2016, the project "Environmental Remediation National Project of ISPRA" (D.M. 18 settembre 2001 n. 468) led to the distribution mapping of several species of conservation interest, including G. cydonium. The results of this research indicated that G. cydonium is mainly located under piers on natural and artificial hard substrates (wrecks, ropes, and nets) and onto concrete vertical walls of these piers, in correspondence with three principal areas (Tosi yards, Ex-Marigeminil wharf, and a military area named 170$)$.

\subsubsection{Porto Cesareo Bay}

Porto Cesareo Bay (SW Apulia) (Figure 1) measures $2500 \mathrm{~m}$ in length and 700-800 m in width, with a maximum depth of $2.5 \mathrm{~m}$ [36]. The bay is linked to the sea through a channel system that allows a moderate water turnover. Water movement, however, is significantly lower than in the open sea [14]. The bottom is primarily constituted of mixed sands, although calcareous boardings, rocks, and pebbles are also present in the central portion of the bay. Sponges were an important component of macrozoobenthos with high covering values and biomasses $[18,37,38]$.

G. cydonium is reported as the most common and relevant sponge species inhabiting this bay. It is described as irregularly massive with a brain-like surface. The species mainly 
settled on calcareous rocky substrates in the middle part of the bay at a depth of 1-2 $\mathrm{m}$ and was usually covered by a thick layer of sediment and frondose macroalgae [14,19,29]. An assemblage of non-sessile specimens, which were markedly flattened in shape and had a smooth surface, was also reported over the soft bottoms [19,30].

The presence of G. cydonium in Porto Cesareo Bay was reported in numerous scientific papers over a period of 28 years (1976-2004), [14,16,18,37-40].

\subsection{Survey Methods}

The present study reports the results of surveys carried out in Marsala Lagoon and Mar Piccolo of Taranto in 2021, and in Porto Cesareo Bay in 2012 and 2020.

The presence of G. cydonium at each study site was detected by scuba divers. The species presence was investigated on all available substrates (sand, stones, debris of human origin, ropes, algae, concrete walls, and Posidonia oceanica rhizomes) and in the same areas where the species has been previously reported (Figure 1). One additional area was sampled in Porto Cesareo Bay (Figure 1). The measurements were taken in situ, along $2 \times 50 \mathrm{~m}$ transects, on horizontal substrates in Porto Cesareo Bay and Marsala Lagoon, and on vertical substrates in Mar Piccolo of Taranto (concrete walls of piers). Sponges were counted and measured with a ruler or caliper. Measures relative to the longest horizontal axis (top view) of G. cydonium were used to estimate the size of each specimen (Figure 2). The density data collected in the present research were compared with literature data for Marsala Lagoon and Porto Cesareo Bay $[19,30,40]$ and with data reported in the Final Technical Report of Environmental Remediation National Project of ISPRA for Mar Piccolo of Taranto; size data collected in the present research were compared with unpublished author's data referring to 1997 for Marsala Lagoon, 2016 for Mar Piccolo of Taranto and 1998 and 2012 for Porto Cesareo Bay.

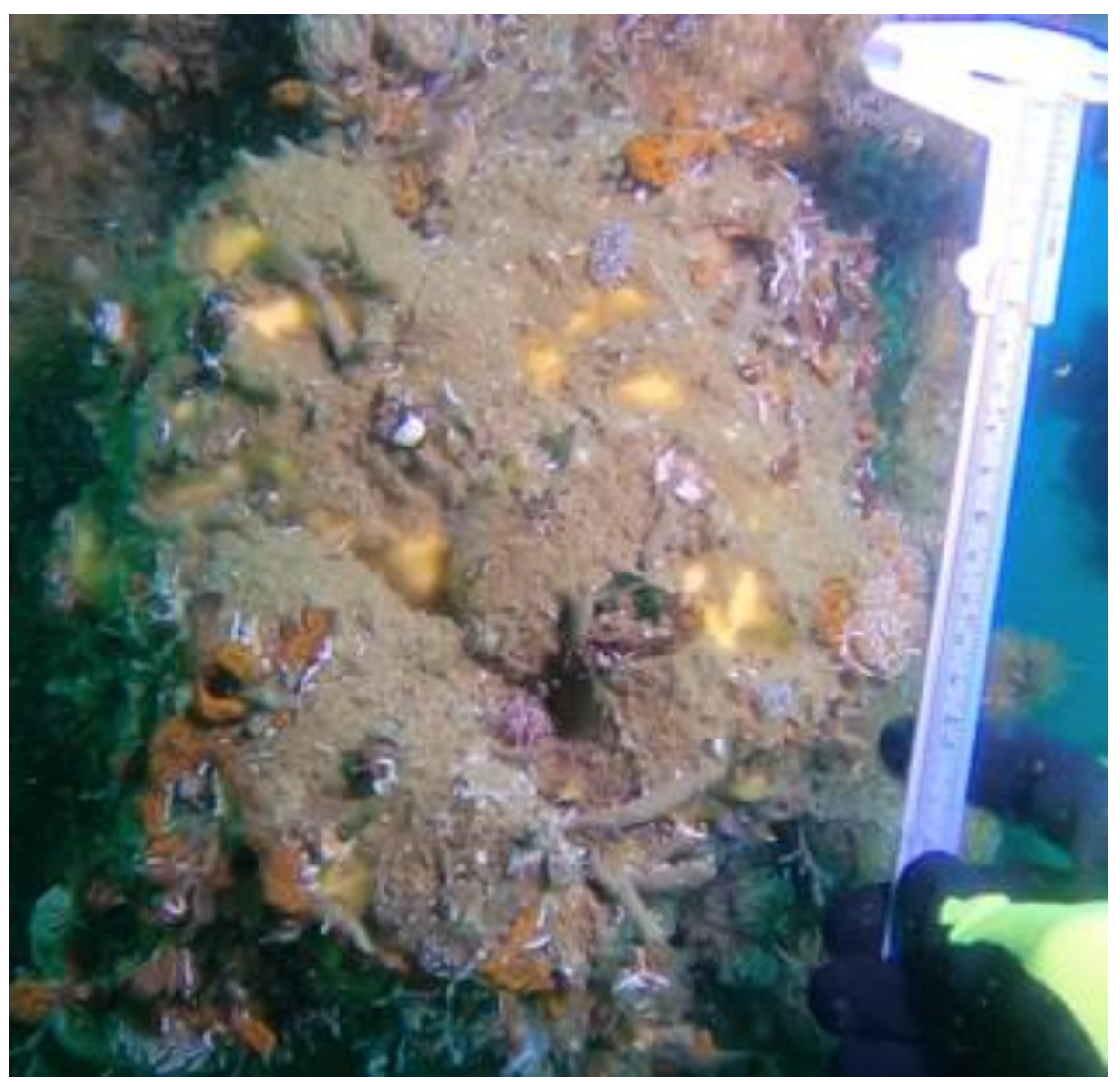

Figure 2. Measurements of Geodia cydonium in Mar Piccolo of Taranto. 


\subsection{Statistical Analysis}

All experimental data were computed as dependent variables using PERMANOVA in an approach similar to parametric ANOVA. Univariate PERMANOVA tests were run on Bray-Curtis similarity matrices with 9999 permutations [41]. Site (S, 3 levels), Time (Start and End, 2 levels) and Type (sessile and non-sessile, nested in Site, 2 levels) factors were used to detect differences in diameter of individuals. Each interaction was individually analyzed using Univariate PERMANOVA tests with the same experimental design. A BrayCurtis similarity matrix with 9999 permutations were used to perform the analyses [41]. If it was impossible to obtain enough permutations for PERMANOVA analysis, the reference $\mathrm{p}$ was obtained using a permutation simulation test (Monte Carlo test). The pairwise test was applied to discover statistically significant differences in each pair of factor levels based on the significance value of PERMANOVA/Monte Carlo tests. All analyses were conducted using PRIMER v6+ PERMANOVA software [42].

\section{Results}

\subsection{Marsala Lagoon}

At Marsala, G. cydonium was white to white-grey. The surface, which was irregularly globose, was often covered by fine sediments and colonized by epibiotic organisms. The present study confirmed the occurrence of sessile specimens of G. cydonium in the same areas as in previous research (Figure 1). They were mostly associated with Posidonia oceanica rhizomes (Figure 3) at a 0.5-2 m depth and on artificial substrates (concrete walls) at an approximately $1 \mathrm{~m}$ depth. A few non-sessile specimens $(n=5)$, obvious products of the accidental detachment of sessile specimens, as suggested by the irregular shape of the sponges and the presence of traces of P. oceanica rhizomes on the surface, were occasionally found on the soft bottom. The rich assemblage of rounded non-sessile specimens covered by red alga Rytiphloea tinctoria, described by many past studies $[11,14,19,25,29,30]$, was not found.

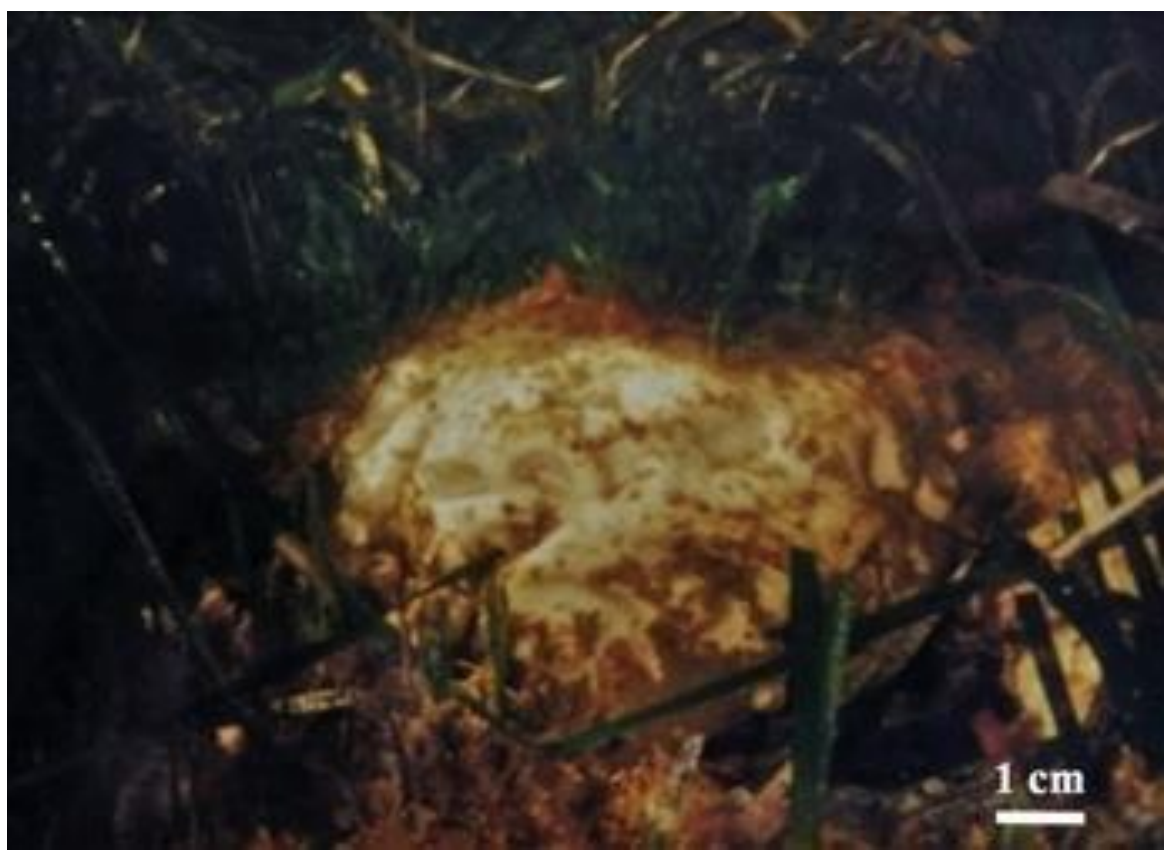

Figure 3. Geodia cydonium associated with Posidonia oceanica rhizomes in Marsala Lagoon.

The mean density of sessile specimens varied between 0.2 and $0.4 / \mathrm{m}^{2}$ on P. oceanica rhizomes and between 0.4 and $0.6 / \mathrm{m}^{2}$ on artificial substrates. The density values recorded in 2021 were lower than those reported in the literature for the same sampling areas (Figure 4).

The sessile specimens sampled in 2021 showed similar dimensional values to those recorded in $1997(16.5 \pm 11.5 \mathrm{~cm}$ versus $18 \pm 11.1 \mathrm{~cm}$, respectively, in the longest horizontal 
axis). In contrast to the 1997 data indicating a wide distribution of size and the presence of small recruits, this study's analysis of size distribution (Figure 5) demonstrated a concentration of sessile specimens in the middle classes $(10-20 \mathrm{~cm}$; peak between 10 and $15 \mathrm{~cm})$, and a complete lack of small recruits $(1-5 \mathrm{~cm})$.

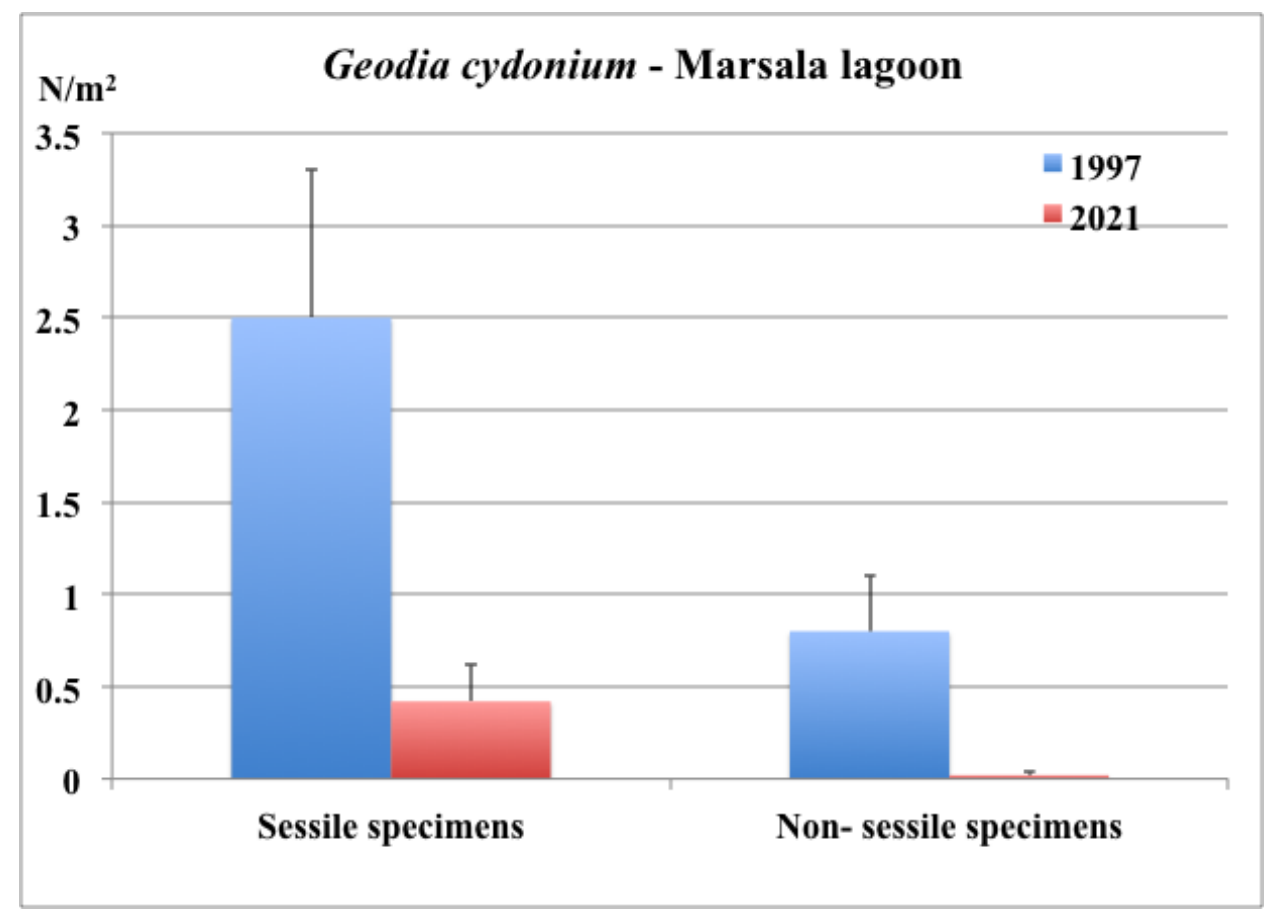

Figure 4. Marsala Lagoon: mean density values of G. cydonium in 1997 [30] and 2021.

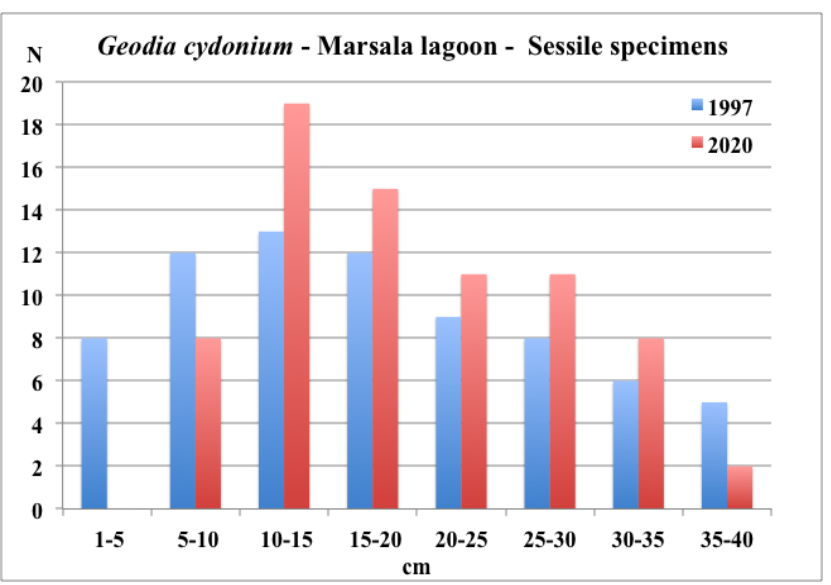

(a)

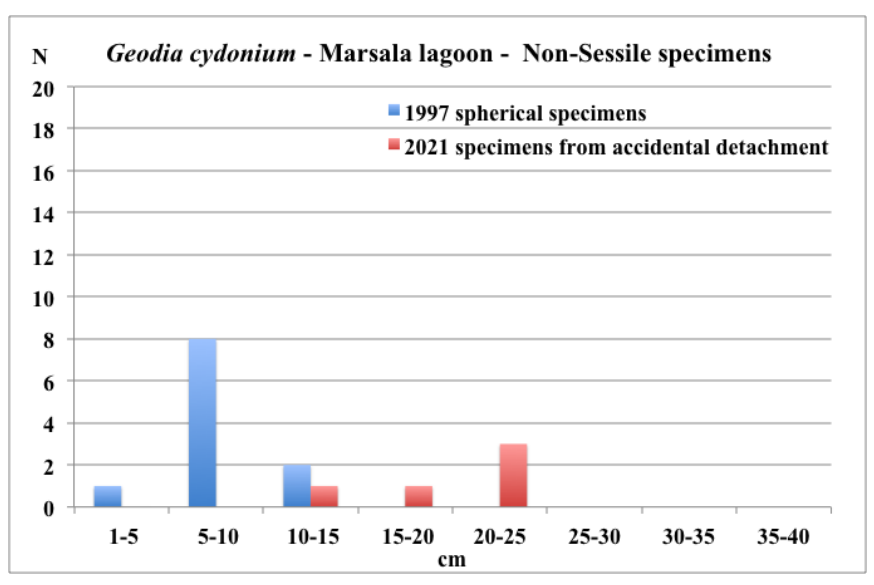

(b)

Figure 5. Marsala Lagoon: size distribution of sessile (a) and non-sessile specimens (b) of G. cydonium in 1997 and 2021. In (b), non-sessile specimens were spherical and covered by red alga Rytiphloea tinctoria in 1997, while in 2021 they were the product of accidental detachment of sessile specimens.

The PERMANOVA analysis did not highlight any level of significance with respect to the size of the specimens for all factors and their interactions. The differences described in the text for all the sites are to be attributed to direct observations on the distribution of the specimens in the minimum to maximum size values. 


\subsection{Mar Piccolo of Taranto}

At Taranto, G. cydonium had a yellowish to gray-yellow color and an irregular, brainlike surface. It was often covered with sediments and colonized by epibiontic organisms that almost completely covered the sponge (Figure 2).

The results of the present study confirmed that the distribution of G. cydonium in Mar Piccolo of Taranto is similar to that observed in 2016 (Environmental Remediation National Project of ISPRA-D.M. 18 September 2001 n. 468). Indeed, the mean density was 0.9 specimens $/ \mathrm{m}^{2}$ on the bottom and 3.8 specimens $/ \mathrm{m}^{2}$ on the vertical walls (Figure 6). Recruits (Figure 7) were locally abundant, with a density of 8-10 specimens $/ \mathrm{m}^{2}$.

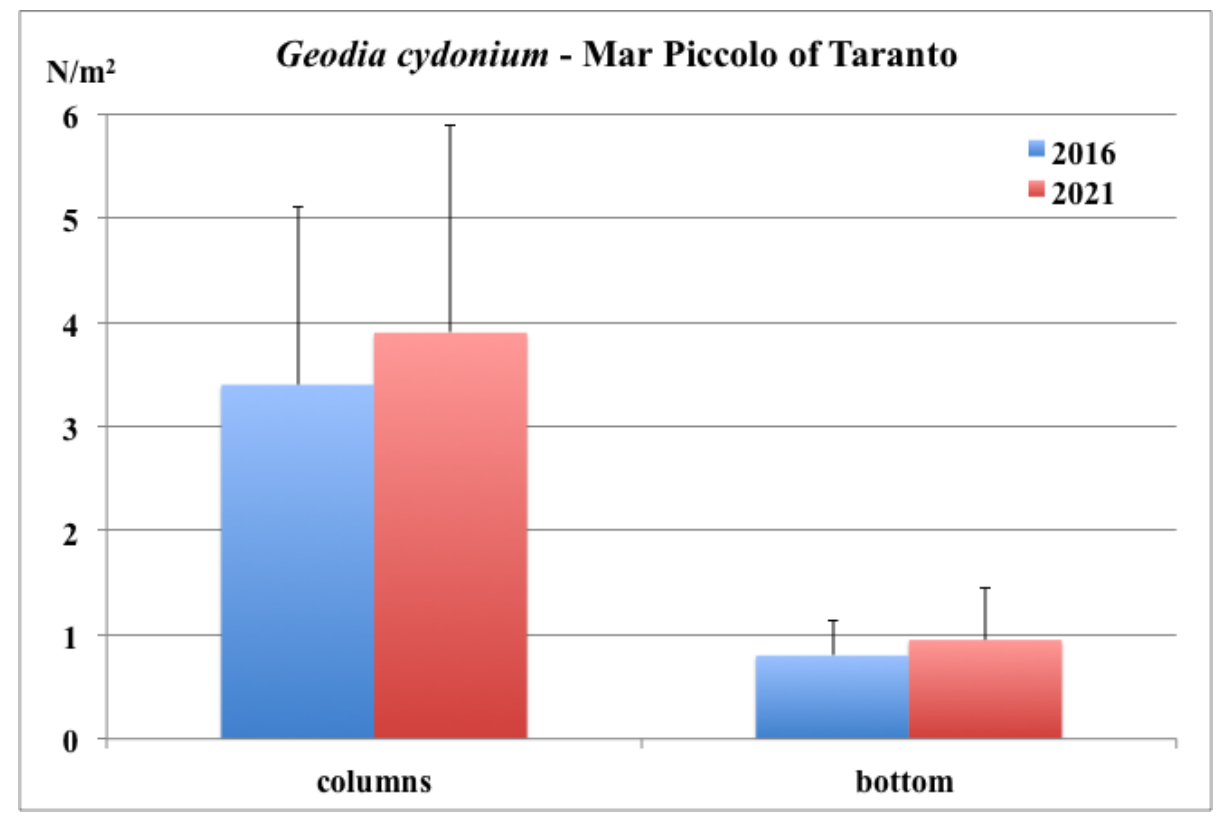

Figure 6. Mar Piccolo of Taranto: mean density values of G. cydonium in 2016 (Technical report on Environmental Remediation National Project of ISPRA) and 2021.

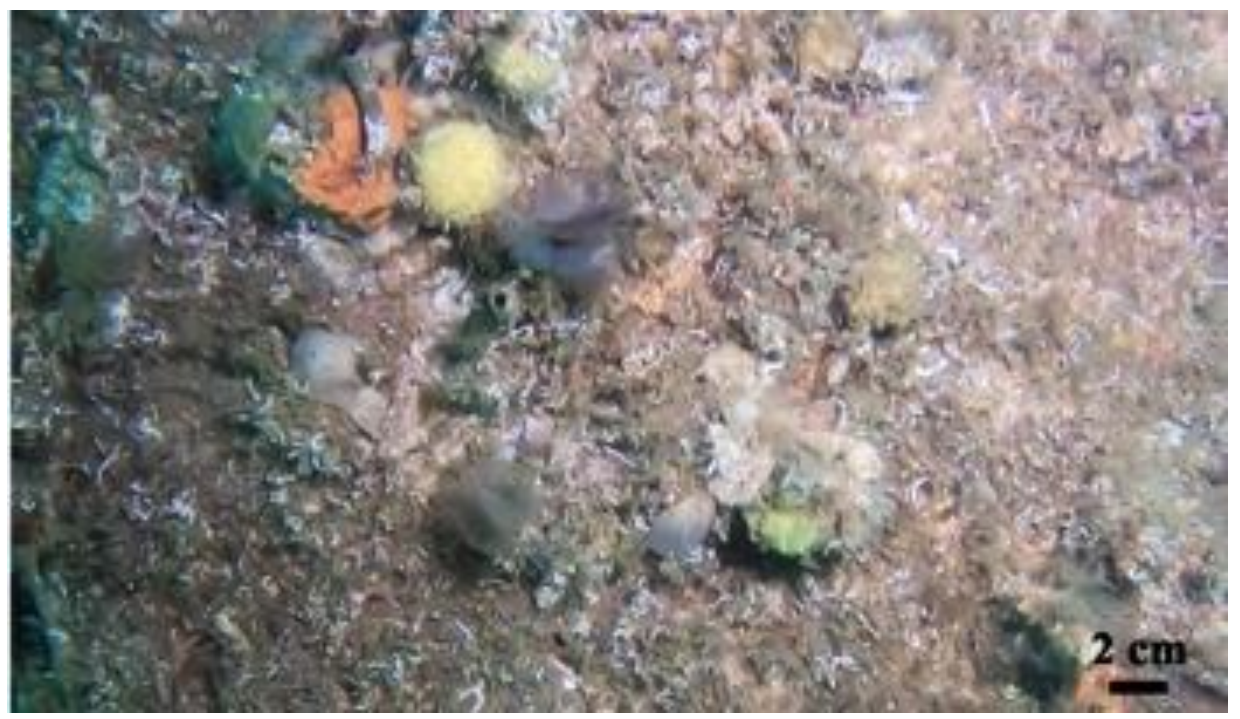

Figure 7. Mar Piccolo of Taranto: recruits of Geodia cydonium.

The specimens sampled in 2021 showed similar dimensional values to those recorded in 2016 (15.2 $\pm 9.5 \mathrm{~cm}$ versus $17.1 \pm 6.3 \mathrm{~cm}$, respectively, in the medium values of longest horizontal axis). The distribution of the longest horizontal axis values, in 2016, was more concentrated in the middle size classes, with a lack of small recruits (major axes $<5 \mathrm{~cm}$ ) and 
big specimens (major axes $>30 \mathrm{~cm}$ ) (Figure 8). In contrast, in 2021, an important recruitment event with numerous small specimens (major axes $<5 \mathrm{~cm}$ ) was observed around the largest specimens. Moreover, several very large specimens (major axes $>40 / 50 \mathrm{~cm}$ ) were observed in the sampling areas.

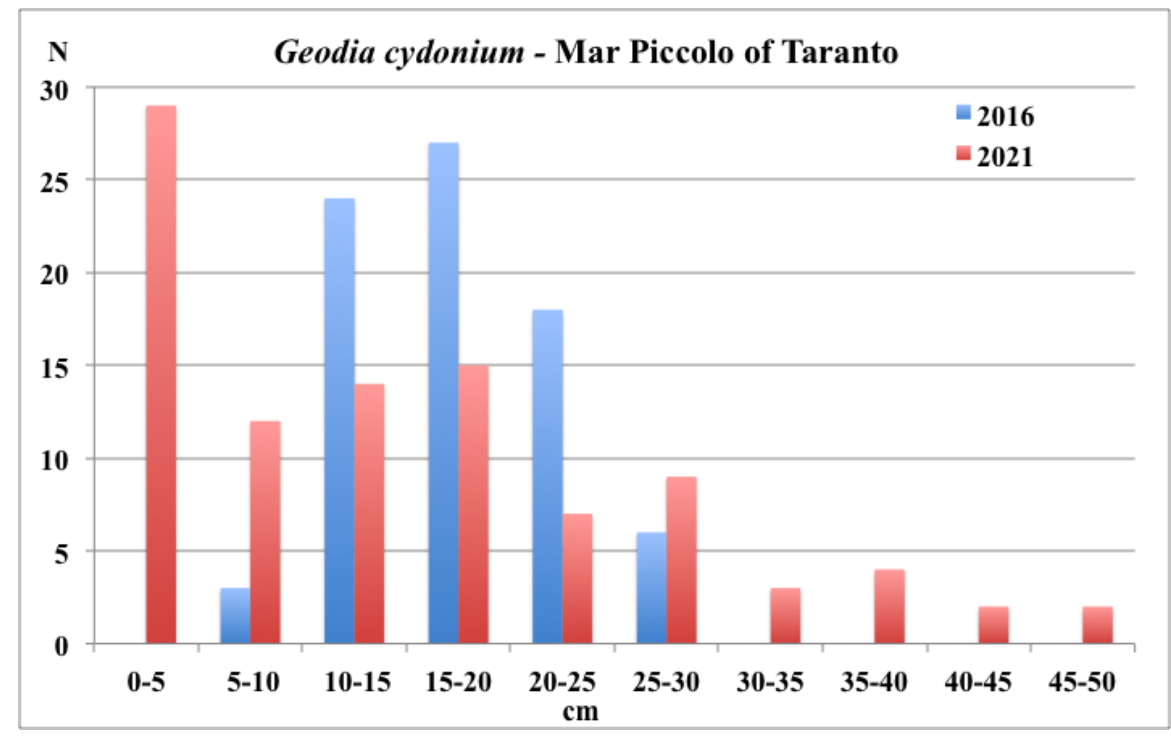

Figure 8. Mar Piccolo of Taranto: size distribution of G. cydonium in 2016 and 2021.

\subsection{Porto Cesareo Bay}

In Porto Cesareo Bay, G. cydonium was monitored in September 2012 and April 2020. The literature data described two distinct forms of this population: sessile, characterized by large specimens of irregular shape and high-density values that are typically associated with hard substrates, and non-sessile morphs, characterized by a flattened shape, small dimensions and low-density values, usually found over uncovered soft bottoms (Figure 9a) [19].

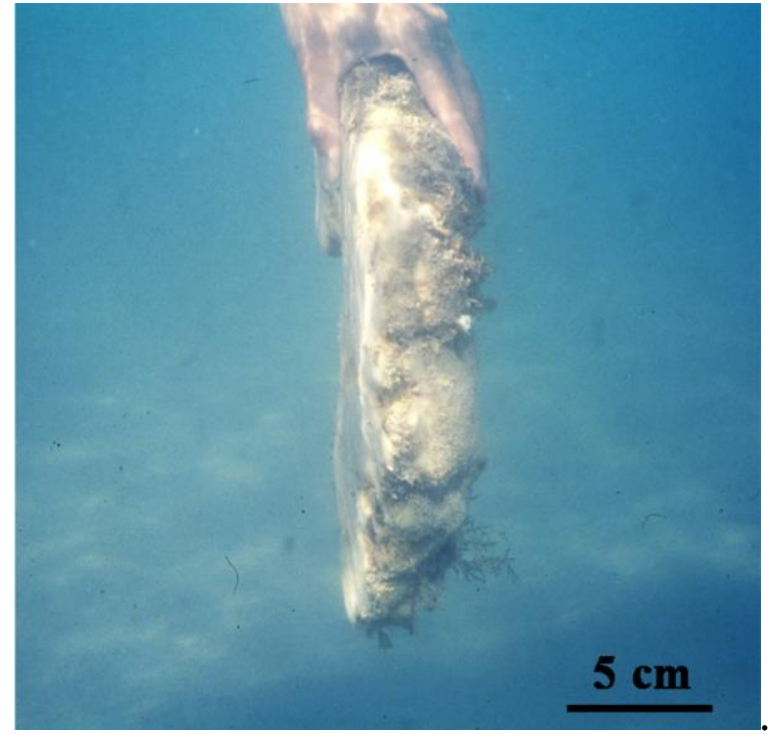

(a)

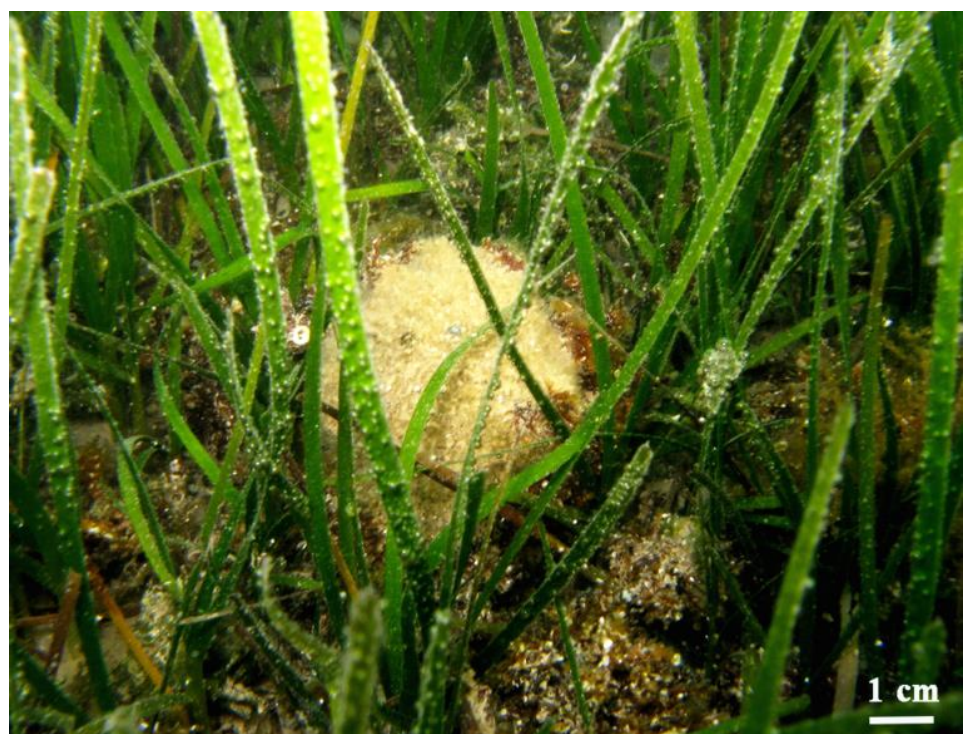

(b)

Figure 9. Porto Cesareo Bay: non-sessile flattened and spherical specimens of G. cydonium in 1996 (a) and 2012 (b), respectively. In (b), the red alga Rytiphloea tinctoria was partially removed from the sponge surface. 
The density of the assemblage of the sessile specimens showed constant values from October 1995 to April 1998. However, starting from July 1998, a progressive density decline was observed [40] and indeed, in 2020, no sessile specimens were observed (Figure 10). The assemblage of the non-sessile flattened specimens showed a similar decreasing trend, but completely disappeared in 2012 (Figure 10). However, the exploration of an additional area (Figure 1) in 2012 permitted the discovery of large storages of non-sessile benthic organisms on the soft bottom, which was inhabited by a large assemblage of rounded non-sessile specimens of G. cydonium. The diameter of these non-sessile specimens, which were completely covered by the red alga Rytiphloea tinctoria (Figure 9b), ranged from 5 to $12 \mathrm{~cm}$ (Figure 11b). Unfortunately, in 2020, this assemblage of non-sessile specimens of G. cydonium also disappeared (Figure 10).

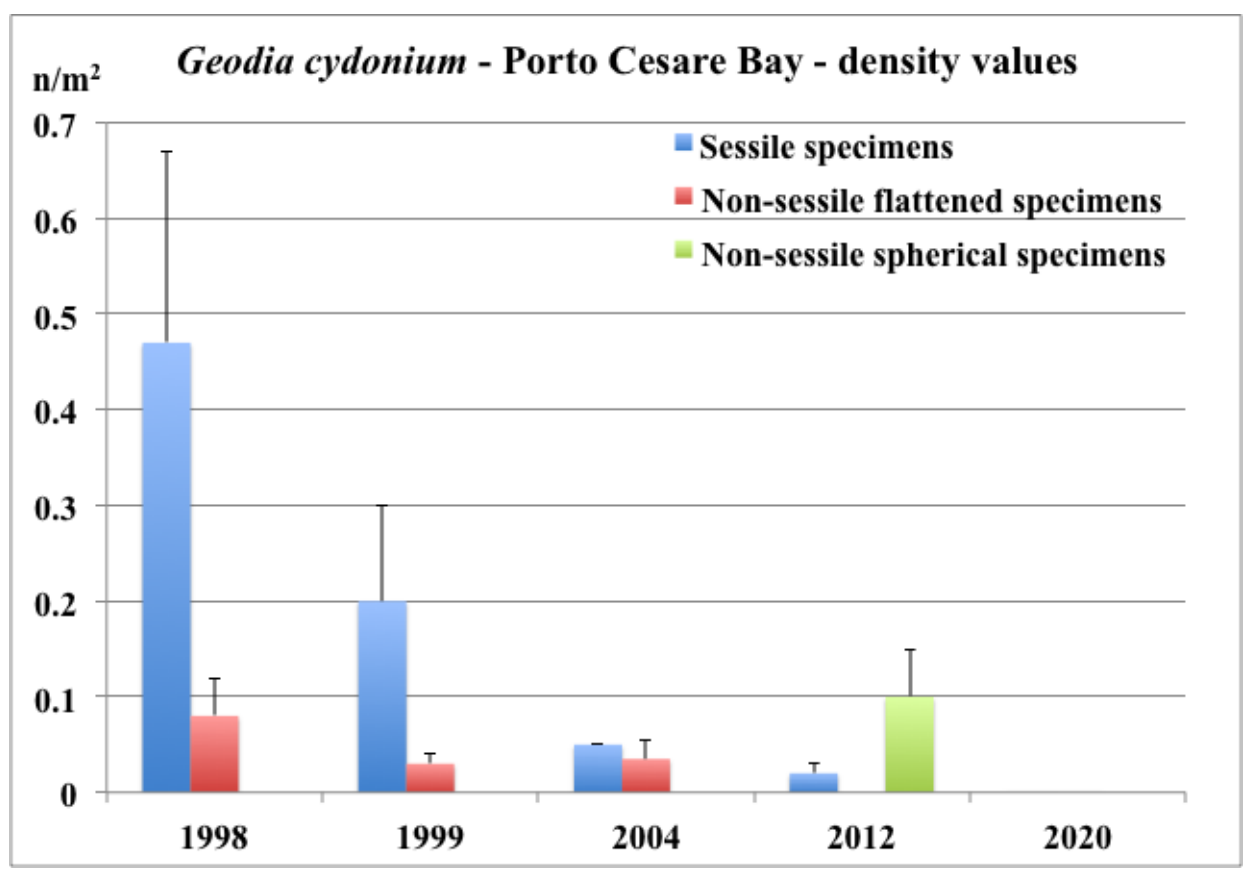

Figure 10. Porto Cesareo Bay: mean density values of sessile and non-sessile specimens of G. cydonium in 1998 [19], 1999, and 2004 [40], 2012 and 2020 (present data).

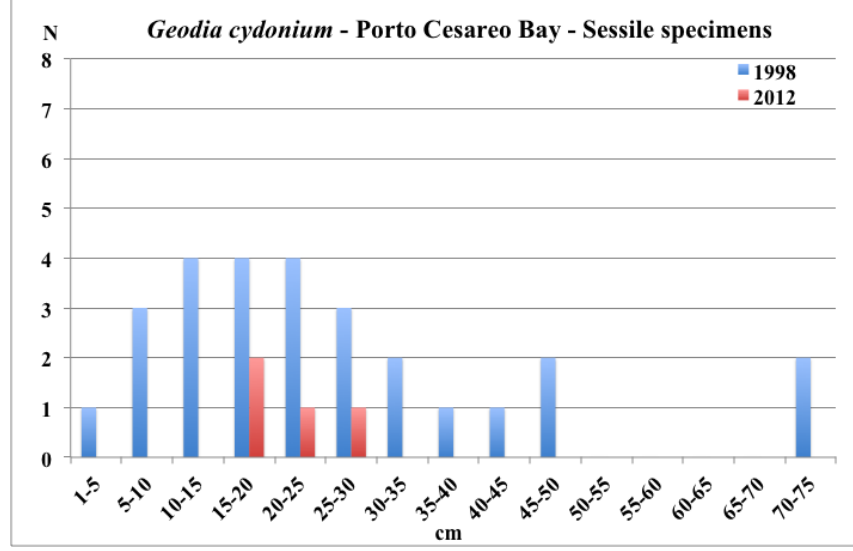

(a)

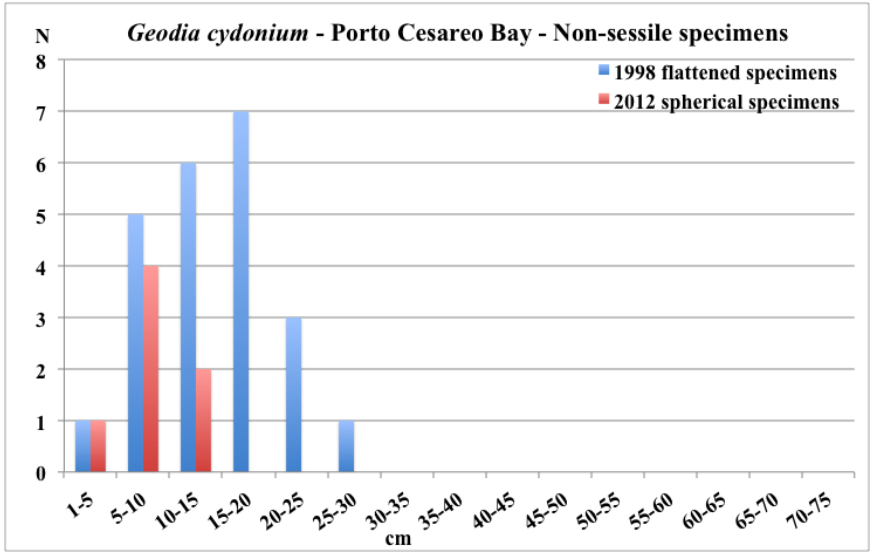

(b)

Figure 11. Porto Cesareo Bay: size distribution of sessile (a) and non-sessile (b) specimens of G. cydonium in 1998 and 2012.

The analysis of the size distribution (Figure 11a) in 1998 showed a wide distribution of the sessile specimens, with the occurrence of several small recruits $(1-5 \mathrm{~cm})$ and some large specimens $(40-75 \mathrm{~cm})$ [19]. During the survey performed in 2012, only a few sessile 
specimens were found $(n=4)$, with the longest horizontal axis values ranging from 15 to $26 \mathrm{~cm}$ (Figure 11a).

\section{Discussion}

The occurrence of G. cydonium in the Mediterranean Sea is well documented in the literature. Rich assemblages were reported at different sites in Italy $[8,19,21,29,43-45]$, Croatia [23], Spain [46], France [47], and Greece [48]. Historically, populations of G. cydonium at these sites were highly abundant and usually characterized by large specimens $[23,40]$. The species was described in association with several benthic communities, such as Cladocora caespitosa (Linnaeus, 1767) biogenic reefs [49], coralligenous concretions [22,50], sciaphilous communities of submerged dark caves [21], P. oceanica meadows [11], and benthopleustophitic algal beds [25].

Distribution data suggest that G. cydonium is a tolerant species, adapted to live in semi-enclosed environments, as well as in conditions of low oxygen, chemical pollution and eutrophication (e.g., Taranto), and within natural sulfur springs (Capo Palinuro caves [21]). Large specimens, presumably of several years of age [24], can, therefore, survive periods of prolonged exposure to potential adverse factors. However, it has been reported that the abundance and the average size of G. cydonium specimens in the Mediterranean Sea have declined since the end of the last century [51]. Indeed, available data for the Mediterranean Sea described the current species distribution as highly fragmented and declining due to several factors, such as increasing human activities affecting water quality, turbidity, and siltation in coastal areas; urban and industrial sewage; coastal development; trawling; aquaculture activities; anchorages; collection abuse; commercial fishing bycatch; global climate change; and, generally, the cumulative effects of multiple stressors at different temporal and spatial scales [24,46,52].

The three studied sites were characterized by low water movement and moderate variability in the mean salinity and temperature values $[27,53,54]$. According to the literature, there have been some important variations in sponge fauna at these sites in recent decades, with a general decline in both species abundance and composition [8,55]. In Marsala and Porto Cesareo, increased anthropogenic activities have probably caused the modification and/or loss of G. cydonium habitats.

In Marsala Lagoon, decreased water circulation and turnover, as a consequence of the closure of the southern opening, led to the burial of bottom depression, which had previously been characterized by extensive bentopleustophytic algal facies of Rytyploea tinctoria [56], associated with non-sessile spherical sponges $[11,25]$. Indeed, a close relationship between the algal thallus and the cortical layer of sponges, with a tight adhesion between sponge and algal tissues, has been described [19]. This peculiar association, beyond its intrinsic and naturalistic value, represented a preferential habitat for numerous small benthic species (mainly amphipods, polychaetes, and gastropods), used in the diets of many fish species [25]. Marked silting also involved the phanerogam Posidonia oceanica that appears, coherently with the Mediterranean scenario [57,58], to be affected by strong regression (unpublished authors' observations) and whose rhizomes constitute an elective substrate for the sponge.

In Porto Cesareo Bay, the presence of rich benthic assemblages with giant G. cydonium specimens has been known since the early 1970s. One of such specimens, which is subspherical in shape and approximately $120 \mathrm{~cm}$ in diameter, is preserved in Porto Cesareo's Museum of Marine Biology. The sponge assemblage, particularly abundant in the central part of the bay and found on limestone flattened outcrops, remained relatively intact until the end of the 1990s when it was defined as a sponge garden [38]. Subsequently, a progressive silting affected the bay, presumably due to the construction of large docks and a consequent navigation increase (Figure 12), which led to the covering of rocky substrates where the species usually lived. The present study indicates the occurrence of the species until 2012, represented by rare and small sessile specimens, distributed over a restricted area, and by small and spherical non-sessile specimens, associated with Rytiphlaea tinctoria 
(Figure 9b). As in Marsala Lagoon, this association, which occurred in a depression on the soft bottom, represented a peculiar trait of the South Italian low water movement environments. In 2020, no specimens of G. cydonium were observed.

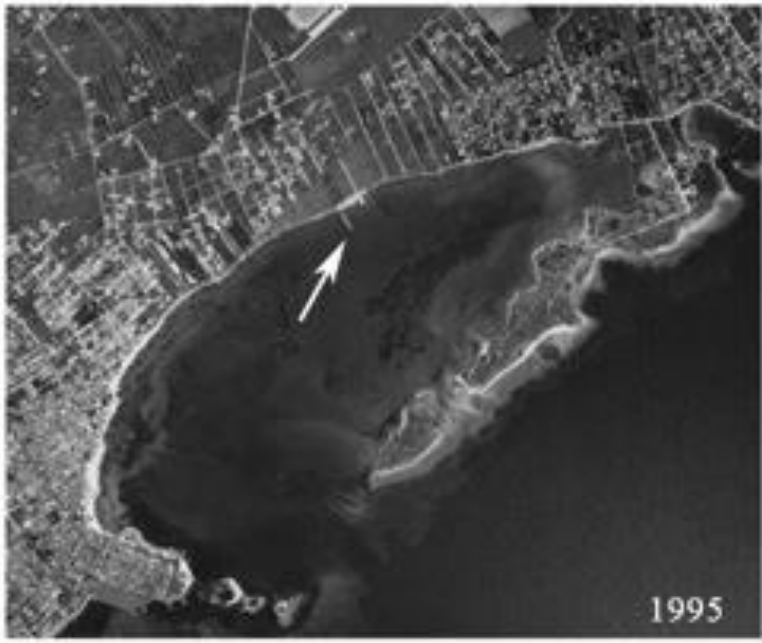

(a)

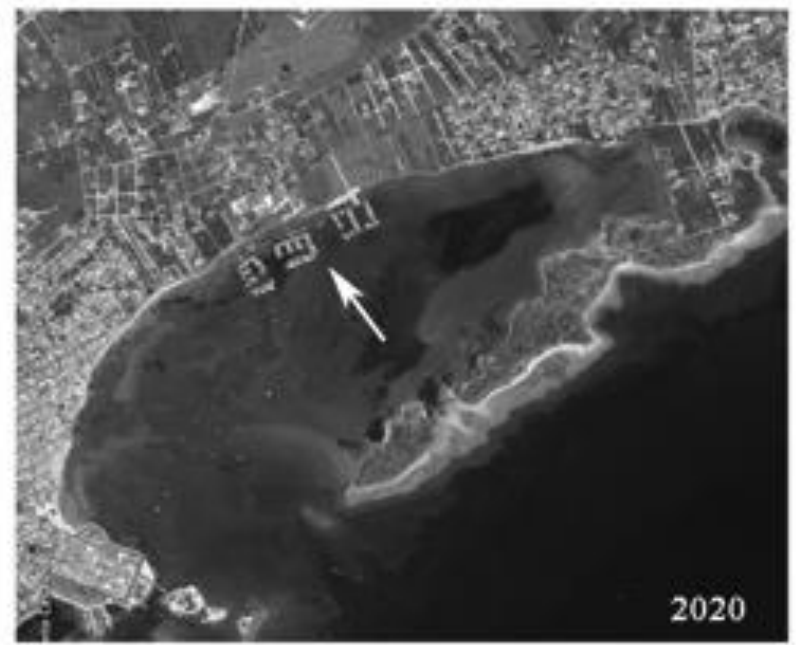

(b)

Figure 12. Porto Cesareo Bay in the early 1990s (a) and 2020 (b). Arrows indicate the floating piers. Maps Data: Google Earth, image @ 2021 TerraMetrics.

According to the literature, beyond silting processes, the increase in water temperature may have also negatively affected the sponge assemblage at Porto Cesareo [40]. The temperature increase in the marine environment is currently considered one of the most severe threats for benthic organisms [59-62]. Thermal stress may have multiple negative effects, including increased mortality, limited growth, faster senescence, reduced recruitments, and the spread of epidemic events [63-69]. In particular, the frequency of sponge disease events seems to be increasing in recent years, determining severe changes in several sponge communities on a global scale [70]. In lagoon environments, such events should be considered a severe threat that can produce profound changes in sponge assemblages since re-colonization is an uncertain and slow process due to the lack of an adequate larval supply [8].

Figure 13 reports the number of days per year with air temperature values higher than the threshold of $35{ }^{\circ} \mathrm{C}$ recorded in the last 50 years in proximity to the studied sites. The number of hot days increased in all studied sites, but more markedly at Mar Piccolo of Taranto and Porto Cesareo. In Mar Piccolo of Taranto, which is characterized by a higher water volume than Porto Cesareo Bay (approximately 20 times), we hypothesize that the increase in air temperature did not determine an increase in water temperature able to affect the persistence and distribution of G. cydonium. Contrarily, in the small and shallow Bay of Porto Cesareo, the increase in air temperature may have had a marked impact on the water mass, thus affecting sponge assemblages. This hypothesis seems to be in accordance with the literature data reporting a significant decline in reproductive activity and massive mortality, with a drastic decline in the size and density values of G. cydonium, at the end of a persistent period of high air temperatures in the summer of 1998 [40].

In addition to the intrinsic naturalistic value, the disappearance of this species is significant for overall fauna biodiversity, as it was an elective substrate for rich and diverse epi- and endobiont fauna [26].

In the last 50 years, Mar Piccolo of Taranto has showed the greatest thermal increase and was subjected to frequent dystrophic events [71,72], which could have led to a considerable temporal heterogeneity of the sponge assemblage. Indeed, the sponge population at this site seems to be subjected to massive mortality events followed by re-colonization 
processes of larvae derived from the external environment, involving the recruitment of different species [8]. Furthermore, changes in sponge assemblages could be due to the intense industrialization of the area and the increased presence of mollusk and fish farms as sources of habitat modification [72].

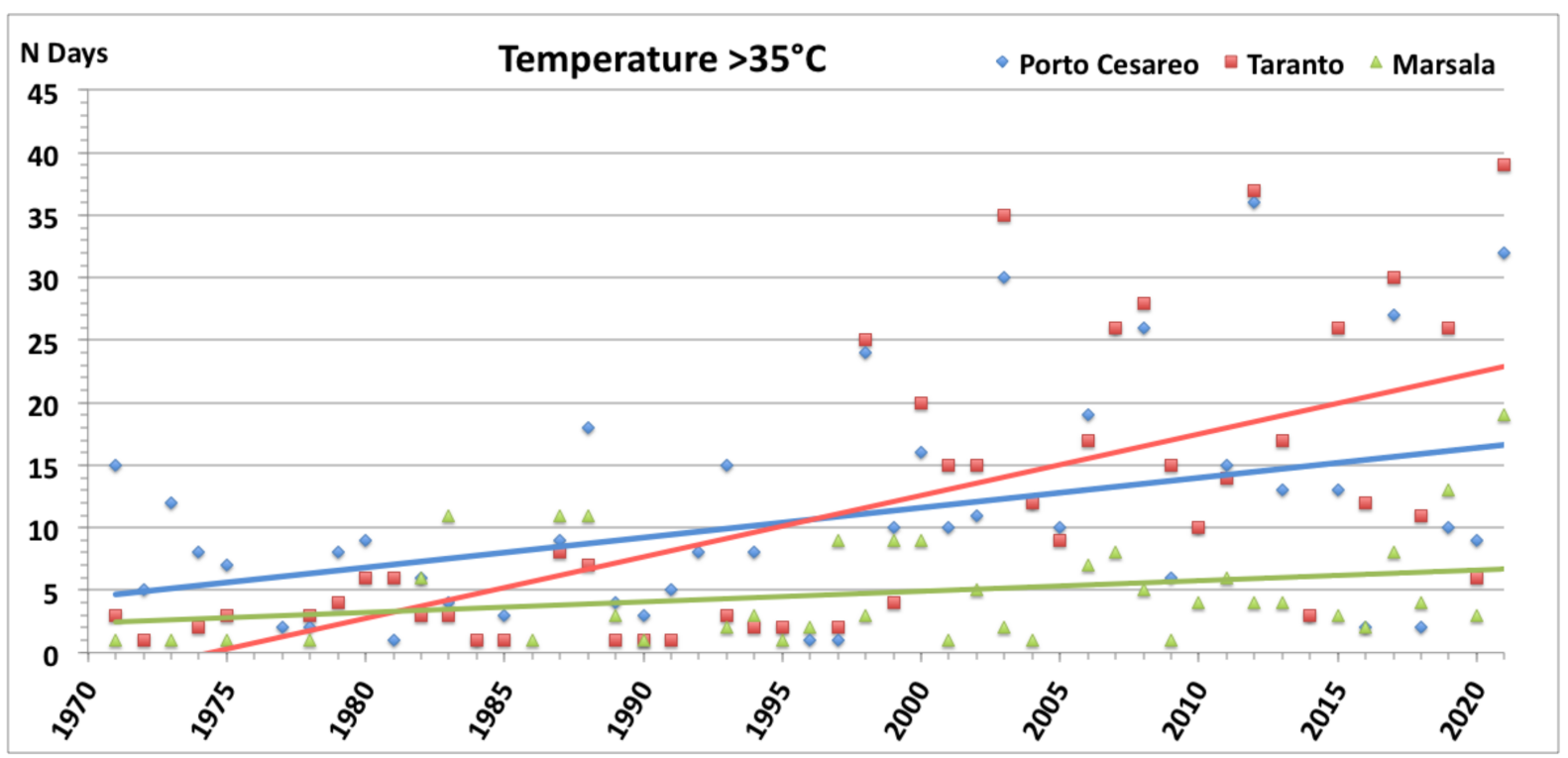

Figure 13. Number of days per year with high values of air temperature $\left(\mathrm{T}>35^{\circ} \mathrm{C}\right)$ recorded in the last 50 years in a meteorological station close to the study sites.

However, the population of G. cydonium appeared to be in a good state of conservation. This could be due to the choice of preferential habitats, which seemed to be represented by vertical artificial substrates, thus protecting the species from dystrophic crises on the bottom. Moreover, species conservation is strictly connected to the conservation of their habitat. This is evident in the case of the military area named 170 (located in the first inlet of Mar Piccolo of Taranto), which is forbidden to civil navigation and any form of anthropogenic fishing-related activity. Such military restrictions had a "marine reserve effect" for G. cydonium specimens, suggested by the highest species densities and dimensional values recorded in the basin (Environmental Remediation National Project of ISPRA). Despite the environmental degradation affecting the internal seas of Taranto, the population of G. cydonium found within the first inlet can be defined as stable and persistent over time. Thus, future perspectives should include gaining more comprehensive knowledge on this population, which is one of the richest and most well-preserved G. cydonium populations in the entire Mediterranean Sea.

Author Contributions: M.M. designed the study, acquired and analyzed the data, contributed to the interpretation of results, wrote the first draft of the manuscript and carried out review \& editing; C.P. analyzed the data with statistical approach and collaborated in the critical revision of the text; F.C. contributed to data acquisition and curation; and G.C. contributed to data acquisition, the interpretation of results and manuscript writing. All authors have read and agreed to the published version of the manuscript.

Funding: This research was partially supported by the Project "Marine Strategy" (ID: I99J21004960005) funded by CoNISMa (Consorzio Interuniversitario per le Scienze del Mare).

Institutional Review Board Statement: Not applicable.

Data Availability Statement: Historical data of air temperature were obtained from the hydrological annals of the Puglia and Sicily regions, which can be found at the following links: https:/ / protezionecivile. puglia.it/centro-funzionale-decentrato/rete-di-monitoraggio/annali-e-dati-idrologici-elaborati/annaliidrologici-parte-i-download/ (accessed on 1 October 2021); http:/ / www.osservatorioacque.it/ (accessed on 15 October 2021). 
Acknowledgments: We wish to thank Roberta Trani and Tamara Lazic for their help in collecting data and Tamara Lazic for her English revision.

Conflicts of Interest: The authors declare no conflict of interest.

\section{References}

1. Steffen, W. Trajectories of the earth system in the Antropocene. Proc. Natl. Acad. Sci. USA 2018, 115, 8252-8259. [CrossRef] [PubMed]

2. Trisos, C.H.; Merow, C.; Pigot, A.L. The projectd timing of abrupt ecological disruption from climate change. Nature 2020, 580, 496-501. [CrossRef] [PubMed]

3. Albano, P.G.; Steger, J.; Bošnjak, M.; Dunne, B.; Guifarro, Z.; Turapova, E.; Hua, Q.; Kaufman, D.S.; Rilov, G.; Zuschin, M. Native biodiversity collapse in the eastern Mediterranean. Proc. R. Soc. B Boil. Sci. 2021, 288, 20202469. [CrossRef] [PubMed]

4. Torresan, S.; Gallina, V.; Gualdi, S.; Bellafiore, D.; Umgiesser, G.; Carniel, S.; Sclavo, M.; Benetazzo, A.; Giubilato, E.; Critto, A. Assessment of Climate Change Impacts in the North Adriatic Coastal Area. Part I: A Multi-Model Chain for the Definition of Climate Change Hazard Scenarios. Water 2019, 11, 1157. [CrossRef]

5. Marzano, C.N.; Baldacconi, R.; Fianchini, A.; Gravina, F.; Corriero, G. Settlement seasonality and temporal changes in hard substrate macrozoobenthic communities of Lesina Lagoon (Apulia, Southern Adriatic Sea). Chem. Ecol. 2007, 23, 479-491. [CrossRef]

6. Cardone, F.; Corriero, G.; Fianchini, A.; Gravina, M.F.; Marzano, C.N. Biodiversity of transitional waters: Species composition and comparative analysis of hard bottom communities from the south-eastern Italian coast. J. Mar. Biol. Assoc. UK 2014, 94, 25-34. [CrossRef]

7. Gristina, M.; Cardone, F.; Carlucci, R.; Castellano, L.; Passarelli, S.; Corriero, G. Abundance, distribution and habitat preference of Hippocampus guttulatus and Hippocampus hippocampus in a semi-enclosed central Mediterranean marine area. Mar. Ecol. 2015, 36, 57-66. [CrossRef]

8. Piscitelli, M.; Corriero, G.; Gaino, E.; Uriz, M.-J. Reproductive cycles of the sympatric excavating sponges Cliona celata and Cliona viridis in the Mediterranean Sea. Invertebr. Biol. 2011, 130, 1-10. [CrossRef]

9. Hirose, Y.; Aini, S.N.; Yamashiro, H. Contact reactions between individuals of the coral-killing sponge, Terpios hoshinota. Zool. Stud. 2021, 60, 41

10. Longo, C.; Cardone, F.; Mercurio, M.; Marzano, C.N.; Pierri, C.; Corriero, G. Spatial and temporal distributions of the sponge fauna insouthern Italian lagoon systems. Mediterr. Mar. Sci. 2015, 17, 174. [CrossRef]

11. Corriero, G. The sponge fauna from the Stagnone di Marsala (Sicily): Taxonomic and ecological observations. Boll. Mus. Ist. Biol. Univ. Genova 1989, 53, 101-113.

12. Corriero, G.; Longo, C.; Mercurio, M.; Marchini, A.; Occhipinti-Ambrogi, A. Benthic taxocoenoses on artificial hard-bottoms in the Venice Lagoon: Spatial distribution and temporal changes in the northern basin. Ital. J. Zool. 2007, 74, 21-29. [CrossRef]

13. Longo, C.; Scalera Liaci, L.; Corriero, G. Note sui poriferi del Mar Grande e del Mar Piccolo di Taranto (Mar Ionio). Biol. Mar. Medit. 2004, 11, 440-443.

14. Corriero, G. Distribuzione ed Ecologia dei Poriferi in Ambienti Cnfinati Mediterranei. Ph.D. Thesis, University of Genoa, Genova, Italy, 1990.

15. Scalera Liaci, L.; Sciscioli, M.; Fiordiponti, F. Distribuzione dei Poriferi del Mar Piccolo di Taranto. Oebalia 1976, 2, 3-19.

16. Pulitzer-Finali, G. A collection of Mediterranean Demospongiae (Porifera) with, in appendix, a list of the Demospongiae hitherto recorded from the Mediterranean Sea. Ann. Mus. Civ. Stor. Nat. Giacomo Doria 1983, 84, 445-621.

17. Mercurio, M. Distribuzione, Ecologia e Sperimentazione di Tecniche di Restocking della Fauna a Poriferi Presso L'insenatura della Strea di Porto Cesareo. Ph.D. Thesis, University of Bari, Bari, Italy, 2000.

18. Mercurio, M.; Longo, C.; Nonnis Marzano, C.; Scalera Liaci, L.; Corriero, G. Demosponge di ambienti lagunari mediterranei. Biol. Mar. Medit. 2004, 11, 444-447.

19. Mercurio, M.; Corriero, G.; Gaino, E. Sessile and non-sessile morphs of Geodia cydonium (Jameson) (Porifera, Demospongiae) in two semi-enclosed Mediterranean bays. Mar. Biol. 2006, 148, 489-501. [CrossRef]

20. Uriz, M.J. Estudio sistematico de las esponjas Astrophorida (Demospongia) de los fondos de pesca de arrastre, entre Tossa y Calella (Cataluña). Bol. Inst. Espa. Oceano 1981, 6, 8-58.

21. Morri, C.; Cinelli, F.; Bianchi, C.N. Sessile epifauna gigantismin a submarine cave with sulphur springs. Cave Diving 1994, 6, 4-9.

22. Bertolino, M.; Cerrano, C.; Bavestrello, G.; Carella, M.; Pansini, M.; Calcina, B. Diversity of Porifera in the Mediterranean coralli-genous accretions, with description of a new species. Zookeys 2013, 336, 1-37. [CrossRef] [PubMed]

23. Santucci, R. La Geodia cydonium come centro di associazione biologica. Mem. CIII Com. Talas It. 1022, 103, 5-19. Available online: http:/ / www.marinespecies.org/aphia.php?p=sourcedetails\&id=354698 (accessed on 5 May 2020).

24. Müller, W.E.; Wimmer, W.; Schatton, W.; Böhm, M.; Batel, R.; Filic, Z. Initiation of an Aquaculture of Sponges for the Sustainable Production of Bioactive Metabolites in Open Systems: Example, Geodia cydonium. Mar. Biotechnol. 1999, 1, 569-579. [CrossRef]

25. Riggio, S.; Sparla, M.P. Notes on fauna inhabiting Rytyphlöea tinctoria (Clem) C Ag aegagropyla in the stagnone Sound (Western Sicily). Rapp. Comm. Int. Mer. Medit. 1985, 29, 143-144.

26. Gherardi, M.; Giangrande, A.; Corriero, G. Epibiontic and endobiontic polychaetes of Geodia cydonium (Porifera, Demospongiae) from the Mediterranean Sea. Hydrobiology 2001, 443, 87-101. [CrossRef] 
27. Magazzù, G. Usefulness of the Marsala lagoon for acquaculture. Nutrients and primary production. Rapp. P-v Réun. Comm. Int. Explor. Scient. Mer. Méditerr. 1977, 24, 81-82.

28. Basset, A.; Galuppo, N.; Sabetta, L. Environmental heterogeneity and benthic macroinvertebrate guilds in Italian lagoons. Transit. Waters Bull. 2006, 1, 48-63.

29. Corriero, G. Note sui popolamenti di poriferi dello Stagnone di Marsala (Sicilia). Nova Thalass. 1984, 6, $213-223$.

30. Mercurio, M.; Corriero, G.; Scalera Liaci, L. Sulla forma non sessile di Geodia cydonium (Jameson) in un ambiente superficiale. Biol. Mar. Medit. 1997, 4, 407-409.

31. Scardi, M.; Vinci, D.; Lanera, P.; Casolaro, R.; Valiante, L.M.; Plastina, N.; Di Dato, P. Studio ambientale per il recupero produttivo del Mar Piccolo di Taranto. AGCI-ICRMARE 1997, 6-74.

32. Capasso, V.; Di Liddo, A.; Notarnicola, F.; Posa, D.; Rinaldi, F. Modelli matematici per il controllo della qualità delle acque costiere. In Proceedings of the Convegno Nazionale Progetto Strategico CNR 'Matematica computazionale', Rome, Italy, 2-4 May 1989.

33. Gaino, E.; Cardone, F.; Corriero, G. Reproduction of the intertidal sponge Hymeniacidon perlevis (Montagu) along a bathymetric gradient. Open Mar. Biol. J. 2010, 4, 47-56. [CrossRef]

34. Tursi, A.; Pastore, M.; Panetta, P. Aspetti ecologici del Mar Piccolo di Taranto: Ascidie, Crostacei Decapodi e Molluschi. In Proceedings of the IV Simposio Nazionale sulla Conservazione della Natura, Bari, Italy, 23-28 April 1974; pp. 93-117.

35. Mastrototaro, F.; D'Onghia, G.; Tursi, A. Spatial and seasonal distribution of ascidians in a semi-enclosed basin of the Mediterranean Sea. J. Mar. Biol. Assoc. UK 2008, 88, 1053-1061. [CrossRef]

36. Passeri, L. Sedimentazione carbonatica attuale e diagenesi precoce nella laguna di Porto Cesareo (Penisola Salentina). Boll. Soc. Geol. Ital. 1974, 92, 3-40.

37. Corriero, G.; Scalera Liaci, L.; Mercurio, M. Il popolamento a Poriferi della Riserva Marina di Porto Cesareo. In Proceedings of the 57th National Congress UZI, San Benetto del Tronto, Italy, 22-26 September 1996; p. 28.

38. Mercurio, M.; Scalera Liaci, L.; Corriero, G. La fauna a poriferi del bacino della Strea di Porto Cesareo (LE). Biol. Mar. Medit. 2001, 8, 403-412.

39. Parenzan, P. Un habitat marino di tipo subtropicale a Porto Cesareo. In Proceedings of the VI Simposio Nazionale sulla Conservazione della Natura, Bari, Italy, 26-29 April 1976; pp. 151-157.

40. Mercurio, M.; Nonnis Marzano, C.; Scalera Liaci, L.; Corriero, G. L'insenatura della Strea di Porto Cesareo (LE): Da sponge gardend a sand bed. In Proceedings of the 65th National Congress UZI, Taormina, Italy, 21-25 September 2004.

41. Anderson, M.J. A new method for non-parametric multivariate analysis of variance. Austral. Ecol. 2001, 26, 32-46.

42. Anderson, M.J.; Gorley, R.N.; Clarke, K.R. PERMANOVA+ for PRIMER: Guide to Software and Statistical Methods; PRIMER-E: Plymouth, UK, 2008.

43. Ponti, M.; Fava, F.; Abbiati, M. Spatial-temporal variability of epibenthic assemblages on subtidal biogenic reefs in the northern Adriatic Sea. Mar. Biol. 2011, 158, 1447-1459. [CrossRef]

44. Turicchia, E.; Poli, D.; Abbiati, M.; Ponti, M. Abundance, size, and growth rate of Geodia cydonium (Demospongiae: Geodiidae) in the northern Adriatic temperate biogenic reefs. In Proceedings of the 40eme Congrès de la Commission Internationale pour l'Exploration Scientifique de la mer Méditerranée. CIESM, Marseille, France, 28 October 2013.

45. Bastari, A.; Beccacece, J.; Ferretti, F.; Micheli, F.; Cerrano, C. Local Ecological Knowledge Indicates Temporal Trends of Benthic Invertebrates Species of the Adriatic Sea. Front. Mar. Sci. 2017, 4, 157. [CrossRef]

46. Ferrer Hernández, F. Esponjas del Cantábrico. Parte III. Myxospongida. IV. Tetraxonida. V. Triaxonida. Trabajos del Museo Nacional de Ciencias Naturales (Zoológica) 1914, 17, 1-46.

47. Topsent, E. Spongiaires de l'Atlantique et de la Méditerranée Provenant des Croisières du Prince Albert ler de Monaco. In Résultats des Campagnes Scientifiques Accomplies par le Prince Albert I. Monac. 1928. Available online: https://www.worldcat.org/title/ spongiaires-de-latlantique-et-de-la-mediterranee-provenant-des-croisieres-du-prince-albert-ier-de-monaco/oclc/458332158 (accessed on 22 November 2021).

48. Voultsiadou, E. Sponge diversity in the Aegean Sea: Check list and new information. Ital. J. Zoöl. 2005, 72, 53-64. [CrossRef]

49. Stjepčević, J.; Parenzan, P. Il Golfo delle Bocche di Cattaro-Condizioni generali e biocenosi bentoniche con carta ecologica delle sue due baie interne. Stud. Mar. 1980, 9, 3-149.

50. Costa, G.; Bavestrello, G.; Micaroni, V.; Pansini, M.; Strano, F.; Bertolino, M. Sponge community variation along the Apulian coasts (Otranto Strait) over a pluri-decennial time span. Does water warming drive a sponge diversity increasing in the Mediterranean Sea? J. Mar. Biol. Assoc. UK 2019, 99, 1519-1534. [CrossRef]

51. Grech, D.; Van De Poll, B.; Bertolino, M.; Rosso, A.; Guala, I. Massive stranding event revealed the occurrence of an overlooked and ecosystem engineer sponge. Mar. Biodivers. 2020, 50, 1-12. [CrossRef]

52. Ponti, M.; Turicchia, E.; Rossi, G.; Cerrano, C. Reef Check Med-Key Mediterranean Marine Species 2001-2020; Reef Check Italia Onlus. Available online: https:/ / doi.org/10.14284/468 (accessed on 5 May 2020).

53. Genchi, C.; Calvo, S.; Lugaro, A.; Ragonese, S. Idrologia di una laguna costiera e caratterizzazione chimico-fisica dei sedimenti recenti in relazione alla distribuzione dei popolamenti vegetali sommersi (lo Stagnone di Marsala). Quad. IRPEM 1983, 4, 23-34.

54. Cinelli, F.; Cognetti, G.; Grasso, M.; Mongelli, S.; Orlando, E.; Pagliai, A.M. Studio Ecologico dell'area Marina di Porto Cesareo; Congedo, Ed.; Studio Ecologico dell'area marina di Porto Cesareo: Lecce, Italy, 1988; pp. 1-388.

55. Gravina, M.F.; Bonifazi, A.; Del Pasqua, M.; Giampaoletti, J.; Lezzi, M.; Ventura, D.; Giangrande, A. Perception of Changes in Marine Benthic Habitats: The Relevance of Taxonomic and Ecological Memory. Diversity 2020, 12, 480. [CrossRef] 
56. Calvo, S.; Ragonese, S. Osservazioni su Rytiphloea tinctoria (Clem.) C. Ag. in forma aegagropila nelle acque dello Stagnone (costa occidentale della Sicilia). Plant Biosyst. 1982, 116, 81-87. [CrossRef]

57. Telesca, L.; Belluscio, A.; Criscoli, A.; Ardizzone, G.; Apostolaki, E.T.; Fraschetti, S.; Gristina, M.; Knittweis, L.; Martin, C.S.; Pergent, G. Seagrass meadows (Posidonia oceanica) distribution and trajectories of change. Sci. Rep. 2015, 5, srep12505. [CrossRef]

58. Calvo, S.; Calvo, R.; Luzzu, F.; Raimondi, V.; Assenzo, M.; Cassetti, F.; Tomasello, A. Performance Assessment of Posidonia oceanica (L.) Delile Restoration Experiment on Dead matte Twelve Years after Planting-Structural and Functional Meadow Features. Water 2021, 13, 724. [CrossRef]

59. Rivetti, I.; Fraschetti, S.; Lionello, P.; Zambianchi, E.; Boero, F. Global Warming and Mass Mortalities of Benthic Invertebrates in the Mediterranean Sea. PLoS ONE 2014, 9, e115655. [CrossRef]

60. Garrabou, J.; Coma, R.; Bensoussan, N.; Bally, M.; Chevaldonné, P.; Cigliano, M.; Diaz, D.; Harmelin, J.G.; Gambi, M.C.; Kersting, D.K.; et al. Mass mortality in Northwestern Mediterranean rocky benthic communities: Effects of the 2003 heat wave. Glob. Chang. Biol. 2009, 15, 1090-1103. [CrossRef]

61. Hirose, E.; Nozawa, Y. Latitudinal Difference in the Species Richness of Photosymbiotic Ascidians Along the East Coast of Taiwan. Zool. Stud. 2020, 59, 19.

62. Kim, H.K.; Chan, B.K.K.; Lee, S.-K.; Kim, W. Biogeography of intertidal and subtidal native and invasive barnacles in Korea in relation to oceanographic current ecoregions and global climatic changes. J. Mar. Biol. Assoc. UK 2020, 100, 1079-1091. [CrossRef]

63. Gaino, E.; Pronzato, R.; Corriero, G.; Buffa, P. Mortality of commercial sponges: Incidence in two mediterranean areas. Bolletino Zoöl. 1992, 59, 79-85. [CrossRef]

64. Rizzello, R.; Corriero, G.; Scalera Liaci, L.; Pronzato, R. Estinzione e ricolonizzazione di Spongia officinalis nello Stagnone di Marsala. Biol. Mar. Medit. 1997, 4, 443-444.

65. Cerrano, C.; Bavestrello, G.; Bianchi, C.N.; Cattaneo-Vietti, R.; Bava, S.; Morganti, C.; Morri, C.; Picco, P.; Sara, G.; Schiaparelli, S.; et al. A catastrophic mass-mortality episode of gorgonians and other organisms in the Ligurian Sea (Northwest- ern Mediterranean), summer 1999. Ecol. Lett. 2000, 3, 284-293. [CrossRef]

66. Zocchi, E.; Basile, G.; Cerrano, C.; Bavestrello, G.; Giovine, M.; Bruzzone, S.; Guida, L.; Carpaneto, A.; Magrassi, R.; Usai, C. ABAand cADPR-mediated effects on respiration and filtration downstream of the temperature-signaling cascade in sponges. J. Cell. Sci. 2003, 116, 629-636. [CrossRef]

67. Pronzato, R.; Manconi, R. Mediterranean commercial sponges: Over 5000 years of natural history and cultural heritage. Mar. Ecol. 2008, 29, 146-166. [CrossRef]

68. Bertolino, M.; Betti, F.; Bo, M.; Cattaneo-Vietti, R.; Pansini, M.; Romero, J.; Bavestrello, G. Changes and stability of a Mediterranean hard bottom benthic community over 25 years. J. Mar. Biol. Assoc. UK 2016, 96, 341-350. [CrossRef]

69. Stabili, L.; Cardone, F.; Alifano, P.; Tredici, S.M.; Piraino, S.; Corriero, G.; Gaino, E. Epidemic mortality of the sponge Ircinia variabilis (Schmidth, 1862) associated to proliferation of a Vibrio bacterium. Microb. Ecol. 2012, 64, 802-813. [CrossRef] [PubMed]

70. Webster, N.S. Sponge disease: A global threat? Environ. Microbiology 2007, 9, 1363-1375.

71. Strusi, A.; Pastore, M. Osservazioni idrografiche nel Mar Grande e nel Mar Piccolo di Taranto. Campagna 1970-71. Oebalia 1975, $1,1-64$.

72. Caroppo, C.; Cardellicchio, N.; Cavallo, R.A. Ciclo annuale del fitoplancton nei mari di Taranto: Influenza della qualità delle acque. Biol. Mar. Medit. 1994, 1, 201-206. 